\title{
Halomonas indalinina sp. nov., a moderately halophilic bacterium isolated from a solar saltern in Cabo de Gata, Almería, southern Spain
}

Correspondence Mercedes Monteoliva-Sánchez mmonteol@ugr.es

\author{
Antonio Cabrera, ${ }^{1}$ Margarita Aguilera, ${ }^{1}$ Susana Fuentes, ${ }^{1}$ Claudia Incerti, ${ }^{1}$ \\ Nick J. Russell, ${ }^{2}$ Alberto Ramos-Cormenzana ${ }^{1}$ \\ and Mercedes Monteoliva-Sánchez ${ }^{1}$
}
${ }^{1}$ Department of Microbiology, Faculty of Pharmacy, University of Granada, Campus Universitario de Cartuja s/n, 18071 Granada, Spain
${ }^{2}$ Microbiology Laboratories, Imperial College London, Wye Campus, Wye, Ashford, Kent TN25 5AH, UK

\begin{abstract}
A moderately halophilic bacterium, strain CG2.1 ${ }^{\top}$, isolated from a solar saltern at Cabo de Gata, a wildlife reserve located in the province of Almeria, southern Spain, was subjected to a polyphasic taxonomic study. This organism was an aerobic, motile, Gram-negative rod that produced orange-pigmented colonies. Strain CG2. $1^{\top}$ was able to grow at salinities of 3-25\% $(\mathrm{w} / \mathrm{v})$ and at temperatures of $15-40^{\circ} \mathrm{C}$. The $\mathrm{pH}$ range for growth was $5-9$. Strain $\mathrm{CG} 2.1^{\top}$ was a heterotroph capable of utilizing various carbohydrates as carbon sources. The organism reduced nitrate and showed phenylalanine deaminase activity. The major fatty acids were $\mathrm{C}_{18: 1} \omega 7 c, \mathrm{C}_{16: 0}$ and $\mathrm{C}_{19: 0}$ cyclo $\omega 8 \mathrm{c}$. The DNA G $+\mathrm{C}$ content was $60.9 \mathrm{~mol} \%$. On the basis of the phenotypic and phylogenetic data, strain $\mathrm{CG} 2.1^{\top}$ appeared to be a member of the genus Halomonas and clustered closely with Halomonas marisflavi (97.1\% 16S rRNA gene sequence similarity). However, the level of DNA-DNA relatedness between the novel isolate and the most closely related Halomonas species was low. On the basis of these data, strain CG2.1 $1^{\top}$ represents a novel member of the genus Halomonas, for which the name Halomonas indalinina is proposed. The type strain is CG2.1 ${ }^{\top}$ $\left(=\right.$ CECT $5902^{\top}=$ LMG $\left.23625^{\top}\right)$.
\end{abstract}

The family Halomonadaceae belongs to the class Gammaproteobacteria, formerly known as the $\gamma$-subgroup of the Proteobacteria (Franzmann et al., 1988), and is characterized as being mainly represented by several halophilic, halotolerant and non-halophilic species belonging to different genera. Halomonas is the largest genus in this family; it includes more than 30 species, most of which have been isolated from saline environments and some of which have been recognized as having potential applications in biotechnology (Ventosa \& Nieto, 1995; Calvo et al., 1998; Margesin \& Schinner, 2001; Martínez-Checa et al., 2002; Arias et al., 2003). Moderately halophilic micro-organisms have been subjected to a variety of taxonomical and ecological studies (Oren, 2002) and the genus Halomonas has been considered as a model system among the moderate halophiles and has been used extensively for investigations concerning both osmoregulatory mechanisms and physiological adaptations (Ventosa et al., 1998; Nieto et al., 2000). Moreover, this genus is a taxon that comprises strains that are metabolically versatile (García et al., 2004). The genus

The GenBank/EMBL/DDBJ accession number for the 16S rRNA gene sequence of strain CG2.1 $1^{\top}$ is AJ427627.
Halomonas encompasses species with an unusually wide range of DNA G $+\mathrm{C}$ contents (about 52-68 mol\%) and has been divided into two phylogenetic groups on the basis of $16 \mathrm{~S}$ and 23S rRNA gene sequences (Arahal et al., 2002).

In the course of screening halophilic micro-organisms isolated from the solar salterns of Cabo de Gata, a wildlife reserve located in the province of Almería, southern Spain, a moderately halophilic Gram-negative bacterial organism, strain $C G 2.1^{\mathrm{T}}$, was characterized by using a polyphasic approach. This approach included a phylogenetic analysis based on 16S rRNA gene sequences, an analysis of genomic relatedness and the determination of various chemotaxonomic and phenotypic properties. The results obtained in this study indicated that strain CG2.1 $1^{\mathrm{T}}$ is a member of the genus Halomonas and that it is clearly distinguishable from the other recognized species in the genus.

Water samples were spread on $\mathrm{MH}$ complex medium supplemented with a balanced mixture of sea salts to give an adequate salts concentration for the growth of marine and moderately halophilic strains. This medium contained $\left(1^{-1}\right)$ $10 \mathrm{~g}$ yeast extract (Difco), $5 \mathrm{~g}$ Proteose Peptone no. 3 (Difco) and $1 \mathrm{~g}$ glucose (Ventosa et al., 1982) and was 
supplemented with the balanced mixture of sea salts described by Subov (1931). The $\mathrm{pH}$ was adjusted to 7.2 with $1 \mathrm{M} \mathrm{NaOH}$. The medium was solidified with Bacto agar (Difco) at $20 \mathrm{~g} \mathrm{l}^{-1}$. The isolate was maintained and routinely grown aerobically on $\mathrm{MH}$ complex medium with $7.5 \%(\mathrm{w} / \mathrm{v})$ total salts at $35^{\circ} \mathrm{C}$, except where indicated otherwise.

The methods used for phenotypic characterization were as described previously in detail (Ventosa et al., 1982; Quesada et al., 1983; Prado et al., 1991; Mata et al., 2002). The salts concentrations required for the growth of strain CG2.1 ${ }^{\mathrm{T}}$ were determined at $35^{\circ} \mathrm{C}$. The strain was cultured in $\mathrm{MH}$ medium containing the following concentrations of a balanced mixture of sea salts (Subov, 1931): 0, 0.5, 3, 5, $7.5,10,15,20,25$ and $30 \%(\mathrm{w} / \mathrm{v})$. Each $50 \mathrm{ml}$ batch of medium was inoculated with $0.1 \mathrm{ml}$ (approx.

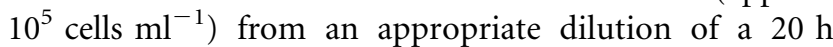
culture of the micro-organism grown in $\mathrm{MH}$ medium containing $7.5 \%(\mathrm{w} / \mathrm{v})$ salts. The cultures were incubated on a rotary shaker. Viable cells were determined from plate counts on solid MH medium at the appropriate salts concentration. Experiments were performed in triplicate. The $\mathrm{pH}$ range for growth was determined in a similar way on $\mathrm{MH}$ medium by adjusting the final $\mathrm{pH}$ to values between 5 and 10 , using $\mathrm{HCl}$ or $\mathrm{NaOH}$. The temperature range was determined as above by incubating the strain at temperatures from 4 to $45^{\circ} \mathrm{C}$.

Transmission electron microscopy (TEM) and scanning electron microscopy (SEM) were used for morphological studies of cells from a $20 \mathrm{~h}$ culture of strain CG2.1 ${ }^{\mathrm{T}}$ grown on the surface of $\mathrm{MH}$ agar plates covered with $\mathrm{MH}$ liquid medium with a salt concentration of $7.5 \%(\mathrm{w} / \mathrm{v})$. The cells used for TEM (model EM 902; Zeiss) were stained with $2 \%$ $(\mathrm{w} / \mathrm{v})$ phosphotungstic acid. The samples used for SEM (model DSM950; Zeiss) were fixed in a $2 \%(\mathrm{v} / \mathrm{v})$ glutaraldehyde solution ( $\mathrm{pH} 7.2$ ), dehydrated in an acetone series, critical-point dried and then coated with gold.

Whole-cell fatty acids of strain CG2.1 ${ }^{\mathrm{T}}$ were analysed by the Analytical Service of the Deutsche Sammlung von Mikroorganismen und Zellkulturen (Braunschweig, Germany) using the MIDI/Hewlett Packard Microbial Identification System, which relies upon high-resolution GC to obtain the fatty acid profile. A moist pellet of cells obtained from cultivation on MH complex medium supplemented with $7.5 \%(\mathrm{w} / \mathrm{v})$ sea salts for 2 days at $35^{\circ} \mathrm{C}$ was used for analysis and the relative amount of each fatty acid was expressed as percentage of the total fatty acids.

DNA was isolated and purified by using the method of Lind \& Ursing (1986). The $\mathrm{G}+\mathrm{C}$ content (mol\%) was determined by using the thermal denaturation method $\left(T_{\mathrm{m}}\right)$ (Marmur \& Doty, 1962) with a Perkin Elmer Lambda 3B spectrophotometer fitted with a temperature-programme accessory. DNA-DNA hybridization studies were performed with the non-radioactive method described by Ziemke et al. (1998). Reference DNA was double-labelled using DIG-11-dUTP and biotin-16-dUTP (Boehringer Mannheim). The labelling was carried out using a nicktranslation kit (Boehringer Mannheim). Phylogenetic analyses based on the 16S rRNA gene sequence of strain CG2.1 ${ }^{\mathrm{T}}$ were performed as described previously (Prado et al., 2006). The sequence obtained was compared with other publicly available $16 \mathrm{~S}$ rRNA gene sequences deposited in the EMBL database. The sequences were aligned by using CLUSTAL W 1.8 (Thompson et al., 1994). The phylogenetic tree was constructed by using the neighbour-joining method with the MEGA3 software package (Kumar et al., 2004).

Table 1 provides a comparison of the taxonomic features of strain CG2.1 $1^{\mathrm{T}}$ and the most closely phylogenetically related species of the genus Halomonas. Cells of strain CG2. $1^{\mathrm{T}}$ were Gram-negative rods and were $1.1-1.3 \times 0.8 \mu \mathrm{m}$ in size. They were motile by means of polar flagella. No spores were observed. On $\mathrm{MH}$ medium containing $7.5 \%$ (w/v) salts, colonies of strain CG2.1 ${ }^{\mathrm{T}}$ were circular with entire margins, flat/slightly convex, smooth and orange-pigmented. Optimum growth occurred at $\mathrm{pH} 7.2$ and $35^{\circ} \mathrm{C}$ in $\mathrm{MH}$ complex medium containing $7.5-10 \%$ total salts. The range of total salts concentrations in which the bacterium grew at $35^{\circ} \mathrm{C}$ was $3-25 \%(\mathrm{w} / \mathrm{v})$. Strain CG $2.1^{\mathrm{T}}$ did not grow in the absence of $\mathrm{NaCl}$, which indicated that the isolate could be assigned to the group of moderately halophilic bacteria (Kushner \& Kamekura, 1988).

The major cellular fatty acids (i.e. comprising up to $85 \%$ ) of strain CG2.1 ${ }^{\mathrm{T}}$ were $\mathrm{C}_{18: 1} \omega 7 c(36.9 \%), \mathrm{C}_{16: 0}(26.8 \%), \mathrm{C}_{19: 0}$ cyclo $\omega 8 c(15.1 \%)$ and $\mathrm{C}_{16: 1} \omega 7 c$ and/or iso- $\mathrm{C}_{15: 0} 2-\mathrm{OH}$ (6.9\%). The DNA G+C content was 60.9 mol\% (determined with the $T_{\mathrm{m}}$ method).

The 16S rRNA gene sequence of strain CG2.1 ${ }^{\mathrm{T}}$ indicated placement within the family Halomonadaceae (Fig. 1). The sequence showed $97.1 \%$ similarity with that of Halomonas marisflavi and less than $93 \%$ similarity with those of related species of the genus Halomonas (92.7\% with Halomonas ventosae, $91.6 \%$ with Halomonas anticariensis, $91.6 \%$ with Halomonas desiderata and $91.6 \%$ with Halomonas organivorans).

Strain $\mathrm{CG} 2.1^{\mathrm{T}}$ produced phenylalanine deaminase, an enzyme that has been previously described only in $H$. desiderata, Halomonas salina and $H$. ventosae (Mata et al., 2002; Martínez-Cánovas et al., 2004a). Moreover, strain CG2.1 $1^{\mathrm{T}}$ shows several taxonomic and physiological differences with respect to $H$. marisflavi (the most closely related species), such as the reduction of nitrate, the hydrolysis of aesculin, anaerobic growth and acid production from sugars (Table 1). DNA-DNA hybridization between strain CG2.1 ${ }^{\mathrm{T}}$ and H. marisflavi JCM $10873^{\mathrm{T}}$ was low $(33.1 \%)$.

The genus Halomonas includes species that are, in some cases, too different to be considered as belonging to the same genus and thus the genus is currently recognized as being very heterogeneous (Arahal et al., 2002). The 16S rRNA gene sequence similarity for strain CG2.1 $1^{\mathrm{T}}$ and $H$. marisflavi JCM 
Table 1. Differential phenotypic characteristics of strain CG2.1 $1^{\top}$ and related type strains of species of the genus $H a l o m o n a s$

Taxa: 1, strain CG2.1 ${ }^{\mathrm{T}}$; 2, H. marisflavi; 3, H. ventosae; 4, H. anticariensis; 5, H. desiderata; 6, H. organivorans; 7, Halomonas taeanensis; 8, Halomonas muralis; 9, Halomonas pantelleriensis; 10, Halomonas campisalis. Data are from Berendes et al. (1996), García et al. (2004), Heyrman et al. (2002), Lee et al. (2005), Mata et al. (2002), Martínez-Cánovas et al. (2004a, b), Mormile et al. (1999), Romano et al. (1996), Yoon et al. (2001) and this study. +, Positive; -, negative; ND, not described.

\begin{tabular}{|c|c|c|c|c|c|c|c|c|c|c|}
\hline Characteristic & 1 & 2 & 3 & 4 & 5 & 6 & 7 & 8 & 9 & 10 \\
\hline Cell morphology & Short rod & Rod & Short rod & Rod & Rod & Rod & Rod & Rod & Rod & Rod \\
\hline Colony pigmentation & Orange & Yellow & Cream & Cream & Cream & Cream & Cream & Cream & Cream & White \\
\hline Oxidase & - & - & + & + & + & - & + & + & + & + \\
\hline $\mathrm{NaCl}$ range $(\%, \mathrm{w} / \mathrm{v})$ & $3-25$ & $0.5-27$ & $3-15$ & $0.5-15$ & $0-20$ & $1.5-30$ & $1-25$ & $0-15$ & $1-15$ & $0.5-15$ \\
\hline $\mathrm{NaCl}$ optimum $(\%, w / v)$ & $7.5-10$ & $0.5-12$ & $6-9$ & 7.5 & $1-5$ & $7.5-10$ & $10-12$ & $2.5-10$ & 10 & 5 \\
\hline $\mathrm{pH}$ range & $5-9$ & $5-10$ & $6-10$ & $6-9$ & $7-11$ & $6-10$ & $7-10$ & $5-10$ & $6-11$ & $8-11$ \\
\hline Temperature range $\left({ }^{\circ} \mathrm{C}\right)$ & $15-40$ & $4-37$ & $15-50$ & $20-45$ & $10-45$ & $15-45$ & $10-45$ & $10-35$ & $10-45$ & $4-50$ \\
\hline Anaerobic growth & - & + & - & - & - & - & - & - & - & - \\
\hline Nitrate reduction & + & - & + & + & + & ND & + & + & + & + \\
\hline \multicolumn{11}{|l|}{ Acid production from: } \\
\hline L-Arabinose & + & + & - & - & - & ND & + & ND & + & - \\
\hline D-Galactose & + & ND & - & - & - & ND & $\mathrm{ND}$ & $\mathrm{ND}$ & + & - \\
\hline D-Glucose & + & + & - & - & - & ND & + & ND & + & - \\
\hline Lactose & - & + & - & - & - & ND & + & ND & - & - \\
\hline Maltose & - & + & - & - & - & ND & + & $\mathrm{ND}$ & + & - \\
\hline D-Mannose & - & + & - & - & - & $\mathrm{ND}$ & + & ND & + & - \\
\hline D-Salicin & - & + & - & - & - & ND & - & $\mathrm{ND}$ & + & - \\
\hline Sucrose & - & + & - & - & - & $\mathrm{ND}$ & $\mathrm{ND}$ & $\mathrm{ND}$ & + & - \\
\hline D-Trehalose & - & + & - & - & - & $\mathrm{ND}$ & + & $\mathrm{ND}$ & + & - \\
\hline \multicolumn{11}{|l|}{ Hydrolysis of: } \\
\hline Aesculin & - & + & - & - & - & + & - & + & + & - \\
\hline Gelatin & + & + & - & - & - & - & - & - & - & - \\
\hline Urea & - & - & - & + & + & $\mathrm{ND}$ & + & $\mathrm{ND}$ & - & - \\
\hline Tween 20 & + & - & + & + & + & $\mathrm{ND}$ & ND & ND & + & + \\
\hline Tween 80 & - & - & - & - & + & + & - & ND & + & - \\
\hline Phenylalanine deaminase & + & - & + & - & + & ND & ND & ND & - & - \\
\hline $\mathrm{H}_{2} \mathrm{~S}$ production & - & - & + & - & + & + & ND & ND & + & - \\
\hline DNA G $+C$ content $(\mathrm{mol} \%)$ & 60.9 & 59.0 & 74.3 & 61.4 & 66.0 & 61.0 & 65.0 & 62.4 & 65.0 & 66.0 \\
\hline
\end{tabular}

$10873^{\mathrm{T}}$ compared with other species of the genus Halomonas suggests that these two micro-organisms could be placed within a novel genus. However, the results obtained in the phenotypic and chemotaxonomic analyses make it possible to assign strain CG2.1 ${ }^{\mathrm{T}}$ to the genus Halomonas. The placement of strain CG2.1 $1^{\mathrm{T}}$ and H. marisflavi within the genus Halomonas might have to be changed if the genus is taxonomically re-evaluated, but this would have to be given very careful consideration in order to avoid excessive and unnecessary renaming.

On the basis of the morphological, phenotypic and genotypic data, strain CG2.1 ${ }^{\mathrm{T}}$ represents a novel species within the genus Halomonas, for which the name Halomonas indalinina sp. nov. is proposed.

\section{Description of Halomonas indalinina sp. nov.}

Halomonas indalinina (in.da.li.ni'na. N.L. n. indalo -inis a prehistoric magical symbol; L. suff. -inus - $a$-um suffix used in the sense of 'belonging to'; N.L. fem. adj. indalinina pertaining to the Indalo, the symbol of the province of Almería, Spain, from where the type strain was isolated).

Cells are straight or slightly curved short rods $1.1-1.3 \times 0.8 \mu \mathrm{m}$ in size. Cells stain Gram-negative and are motile by means of polar flagella. Non-spore-forming. On MH complex solid medium containing $7.5 \%(w / v)$ total salts (mixture of sea salts), the bacteria grow in orange, flat/ slightly convex, smooth and circular/slightly irregular colonies. Moderately halophilic; growth occurs in total salts concentrations of 3-25\% (w/v), with optimum growth at $7.5-10 \%(\mathrm{w} / \mathrm{v})$. No growth in the absence of salt. Growth occurs at $15-40{ }^{\circ} \mathrm{C}$ and at $\mathrm{pH} 5-9$. Strictly aerobic. Catalase is produced and gelatin and Tween 20 are hydrolysed. Negative in tests for oxidase and indole and in methyl red and Voges-Proskauer tests. Casein, starch, aesculin, DNA, tyrosine and Tween 80 are not hydrolysed. Phosphatase and phenylalanine deaminase are produced, but urease is not produced. Nitrate is reduced to nitrite. $\mathrm{H}_{2} \mathrm{~S}$ is not produced 


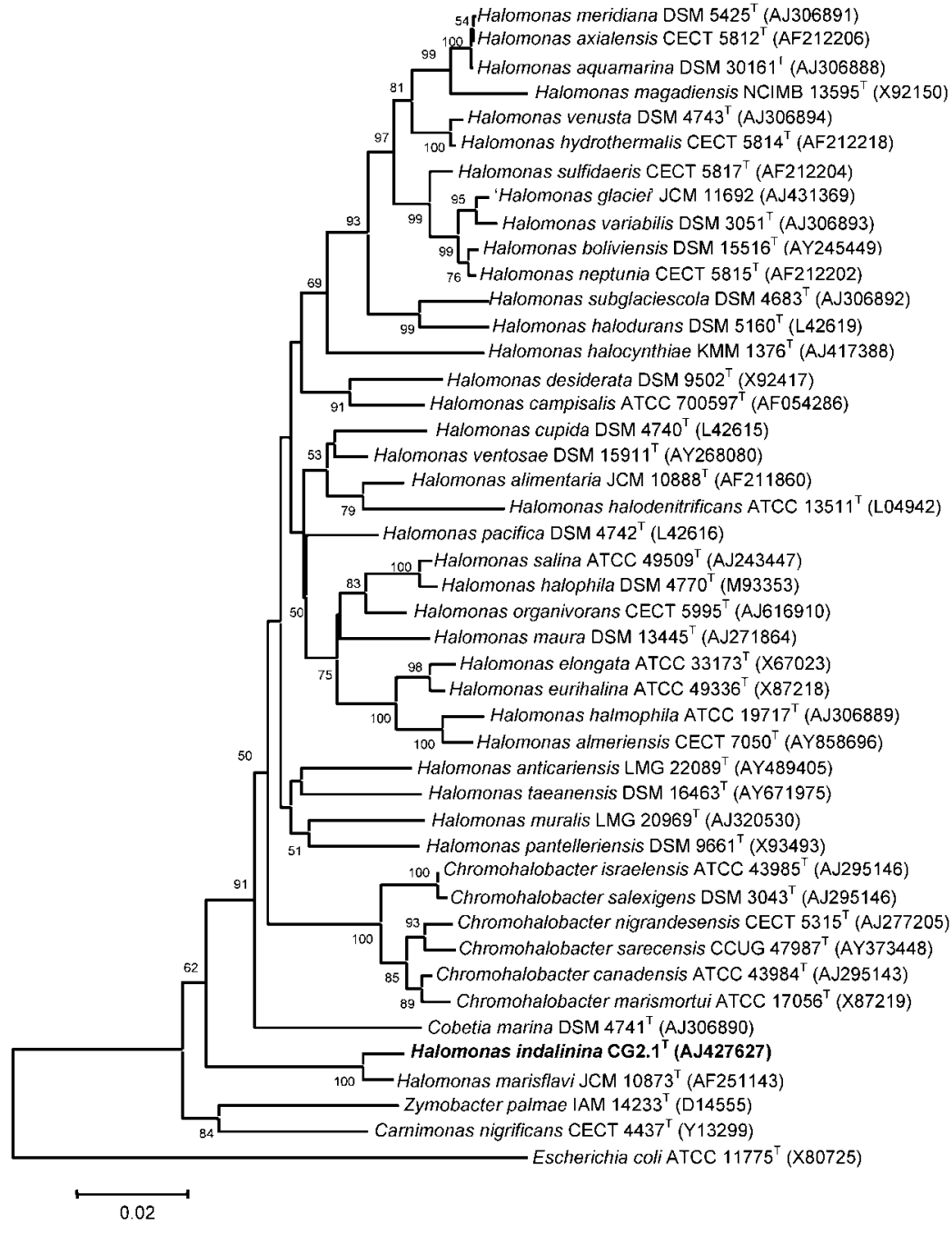

Fig. 1. Neighbour-joining phylogenetic tree, based on 16S rRNA gene sequences, showing the relationships between strain CG2.1 $1^{\top}$ and species of the genera Halomonas, Chromohalobacter, Zymobacter, Cobetia and Carnimonas. GenBank accession numbers are given in parentheses. Escherichia coli was used as the outgroup. Bootstrap percentages greater than $50 \%$ are shown. Bar, 0.02 substitutions per nucleotide position. from L-cysteine. Acids are produced from L-arabinose, Dgalactose and D-glucose, but not from D-cellobiose, lactose, maltose, D-mannose, D-salicin, sucrose, D-trehalose or Dxylose. The following organic compounds are utilized as sole carbon and energy sources: acetate, adonitol, L-arabinose, D-cellobiose, citrate, formate, D-fructose, fumarate, Dgalactose, gluconate, D-glucose, lactate, lactose, malate, maltose, D-mannitol, D-mannose, pyruvate and sucrose. myo-Inositol, propionate, L-rhamnose, $\mathrm{D}$-sorbitol and $\mathrm{D}$ xylose are not utilized. The following compounds are used as sole carbon, nitrogen and energy sources: L-arginine, isoleucine, L-lysine, L-serine and L-valine. Alanine, Lhistidine, L-ornithine and L-tryptophan are not utilized. Susceptible to cefoxitin, chloramphenicol, neomycin, polymyxin $\mathrm{B}$ and rifampicin. The major fatty acids are $\mathrm{C}_{18: 1} \omega 7 c$, $\mathrm{C}_{16: 0}$ and $\mathrm{C}_{19: 0}$ cyclo $\omega 8 \mathrm{c}$ when cells are grown on $\mathrm{MH}$ medium containing $7.5 \%(\mathrm{w} / \mathrm{v})$ total salts. The DNA G $+\mathrm{C}$ content is $60.9 \mathrm{~mol} \%\left(T_{\mathrm{m}}\right)$.

The type strain, CG2.1 ${ }^{\mathrm{T}}\left(=\mathrm{CECT} 5902^{\mathrm{T}}=\mathrm{LMG} 23625^{\mathrm{T}}\right)$, was isolated from a water sample from a solar saltern at Cabo de Gata, Almería, Spain.

\section{Acknowledgements}

We are grateful to Dr Jean Euzéby for etymological advice. This study was supported by grants from the Plan Andaluz de Investigación, Spain (research group CVI 190).

\section{References}

Arahal, D. R., Ludwig, W., Schleifer, K. H. \& Ventosa, A. (2002). Phylogeny of the family Halomonadaceae based on $23 \mathrm{~S}$ and $16 \mathrm{~S}$ rDNA sequence analyses. Int J Syst Evol Microbiol 52, 241-249.

Arias, S., Del Moral, A., Ferrer, M. R., Tallon, R., Quesada, E. \& Bejar, V. (2003). Mauran, an exopolysaccharide produced by the halophilic bacterium Halomonas maura, with a novel composition and interesting properties for biotechnology. Extremophiles 7, 319-326.

Berendes, F., Gottschalk, G., Heine-Dobbernack, E., Moore, E. R. B. \& Tindall, B. J. (1996). Halomonas desiderata sp. nov., a new alkaliphilic, halotolerant and denitrifying bacterium isolated from a municipal sewage works. Syst Appl Microbiol 19, 158-167.

Calvo, C., Martínez-Checa, F., Mota, A., Bejar, V. \& Quesada, E. (1998). Effect of cations, $\mathrm{pH}$, and sulfate content on the viscosity and emulsifying activity of the Halomonas eurihalina exopolysaccharide. J Ind Microbiol Biotechnol 20, 205-209. 
Franzmann, P. D., Wehmeyer, U. \& Stackebrandt, E. (1988). Halomonadaceae fam. nov., a new family of the class Proteobacteria to accommodate the genera Halomonas and Deleya. Syst Appl Microbiol 11, 16-19.

García, M. T., Mellado, E., Ostos, J. C. \& Ventosa, A. (2004). Halomonas organivorans sp. nov., a moderate halophile able to degrade aromatic compounds. Int J Syst Evol Microbiol 54, 1723-1728.

Heyrman, J., Balcaen, A., De Vos, P. \& Swings, J. (2002). Halomonas muralis sp. nov., isolated from microbial biofilms colonizing the walls and murals of the Saint-Catherine chapel (Castle Herberstein, Austria). Int J Syst Evol Microbiol 52, 2049-2054.

Kumar, S., Tamura, K. \& Nei, M. (2004). MEGA3: integrated software for molecular evolutionary genetics analysis and sequence alignment. Brief Bioinform 5, 150-163.

Kushner, D. J. \& Kamekura, M. (1988). Physiology of halophilic eubacteria. In Halophilic Bacteria, vol. I, pp. 109-140. Edited by F. Rodríguez-Valera. Boca Raton, FL: CRC Press.

Lee, J.-C., Jeon, C. O., Lim, J.-M., Lee, S.-M., Lee, J.-M., Song, S.-M., Park, D.-J., Li, W.-J. \& Kim, C.-J. (2005). Halomonas taeanensis sp. nov., a novel moderately halophilic bacterium isolated from a solar saltern in Korea. Int J Syst Evol Microbiol 55, 2027-2032.

Lind, E. \& Ursing, J. (1986). Clinical strains of Enterobacter agglomerans (synonyms, Erwinia herbicola, Erwinia milletiae) identified by DNA-DNA hybridization. Acta Pathol Microbiol Immunol Scand $[B]$ 94, 205-213.

Margesin, R. \& Schinner, F. (2001). Potential of halotolerant and halophilic microorganisms for biotechnology. Extremophiles 5, 73-83.

Marmur, J. \& Doty, P. (1962). Determination of the base composition of deoxyribonucleic acid from its thermal denaturation temperature. J Mol Biol 5, 109-118.

Martínez-Cánovas, M. J., Quesada, E., Llamas, I. \& Bejar, V. (2004a). Halomonas ventosae sp. nov., a moderately halophilic, denitrifying, exopolysaccharide-producing bacterium. Int J Syst Evol Microbiol 54, 733-737.

Martínez-Cánovas, M. J., Bejar, V., Martínez-Checa, F. \& Quesada, E. (2004b). Halomonas anticariensis sp. nov., from Fuente de Piedra, a saline-wetland wildfowl reserve in Málaga, southern Spain. Int J Syst Evol Microbiol 54, 1329-1332.

Martínez-Checa, F., Toledo, F. L., Vílchez, R., Quesada, E. \& Calvo, C. (2002). Yield production, chemical composition and functional properties of emulsifier $\mathrm{H} 28$ synthesized by Halomonas eurihalina strain H-28 in media containing various hydrocarbons. Appl Microbiol Biotechnol 58, 358-363.

Mata, J. A., Martínez-Cánovas, M. J., Quesada, E. \& Bejar, V. (2002). A detailed phenotypic characterization of the type strains of Halomonas species. Syst Appl Microbiol 25, 360-375.

Mormile, M. R., Romine, M. F., García, M. T., Ventosa, A., Bailey, T. J. \& Peyton, B. M. (1999). Halomonas campisalis sp. nov., a denitrifying, moderately haloalkaliphilic bacterium. Syst Appl Microbiol 22, 551-558.

Nieto, J. J., Vargas, C. \& Ventosa, A. (2000). Osmoprotection mechanisms in the moderately halophilic bacterium Halomonas elongata. In Recent Research Developments in Microbiology, vol. 4, part I, pp. 43-54. Edited by S. G. Pandalai. Trivandrum, India: Research Signpost.

Oren, A. (2002). Diversity of halophilic microorganisms: environments, phylogeny, physiology, and applications. J Ind Microbiol Biotechnol 28, 56-63.

Prado, B., Del Moral, A., Quesada, E., Ríos, R., Monteoliva-Sanchez, M., Campos, V. \& Ramos-Cormenzana, A. (1991). Numerical taxonomy of moderately halophilic Gram negative rods isolated from the Salar of Atacama, Chile. Syst Appl Microbiol 14, 275-281.

Prado, B., Lizama, C., Aguilera, M., Ramos-Cormenzana, A., Fuentes, S., Campos, V. \& Monteoliva-Sánchez, M. (2006). Chromohalobacter nigrandesensis sp. nov., a moderately halophilic Gram-negative bacterium isolated from Lake Tebenquiche on the Atacama Saltern, Chile. Int J Syst Evol Microbiol 56, 647-651.

Quesada, E., Ventosa, A., Rodríguez-Valera, F., Megías, L. \& Ramos-Cormenzana, A. (1983). Numerical taxonomy of moderately halophilic Gram-negative bacteria from hypersaline soils. J Gen Microbiol 129, 2649-2657.

Romano, I., Nicolaus, B., Lama, L., Manca, M. C. \& Gambacorta, A. (1996). Characterization of a haloalkalophilic strictly aerobic bacterium, isolated from Pantelleria Island. Syst Appl Microbiol 19, 326-333.

Subov, N. N. (1931). Oceanographical Tables. Moscow: USSR Oceanographic Institute Hydrometeorological Commission.

Thompson, J. D., Higgins, D. G. \& Gibson, T. J. (1994). ClUSTAL W: improving the sensitivity of progressive multiple sequence alignment through sequence weighting, position-specific gap penalties and weight matrix choice. Nucleic Acids Res 22, 4673-4680.

Ventosa, A. \& Nieto, J. J. (1995). Biotechnological applications and potentialities of halophilic microorganisms. World J Microbiol Biotechnol 11, 85-94.

Ventosa, A., Quesada, E., Rodriguez-Valera, R., Ruiz-Berraquero, F. \& Ramos-Cormenzana, A. (1982). Numerical taxonomy of moderately Gram negative rods. J Gen Microbiol 128, 1959-1968.

Ventosa, A., Nieto, J. J. \& Oren, A. (1998). Biology of moderately halophilic aerobic bacteria. Microbiol Mol Biol Rev 62, 504-544.

Yoon, J.-H., Choi, S. H., Lee, K.-C., Kho, Y. H., Kang, K. H. \& Park, Y.-H. (2001). Halomonas marisflavae sp. nov., a halophilic bacterium isolated from the Yellow Sea in Korea. Int J Syst Evol Microbiol 51, 1171-1177.

Ziemke, F., Höfle, M. G., Lalucat, J. \& Rosselló-Mora, R. (1998). Reclassification of Shewanella putrefaciens Owen's genomic group II as Shewanella baltica sp. nov. Int J Syst Bacteriol 48, 179-186. 